\title{
Erratum to: The ultimate radiochemical nightmare: upon radio-iodination of Botulinum neurotoxin $A$, the introduced iodine atom itself seems to be fatal for the bioactivity of this macromolecule
}

Janneke van Uhm

\section{Erratum}

After publication of the manuscript [1], it emerged there have been a mistake in Table 1. At step 2, $50 \mu \mathrm{L}$ phosphate buffer (0.5 M, pH 7.4) is added in stead of $250 \mu \mathrm{L}$ which is described.

We apologise for any inconvenience.

Received: 19 November 2014 Accepted: 23 February 2015

Published online: 26 January 2016

\section{References}

1. Van Uhm JIM, Visser GWM, Van der Schans MJ, Geldof AA, Meuleman EJH,

Nieuwenhuijzen JA (2015) The ultimate radiochemical nightmare: upon radio-iodination of Botulinum neurotoxin $A$, the introduced iodine atom itself seems to be fatal for the bioactivity of this macromolecule. EJNMMI Res 5(1):5

- Convenient online submission

Rigorous peer review

- Immediate publication on acceptance

- Open access: articles freely available online

- High visibility within the field

Retaining the copyright to your article 